\title{
Melanin biosynthesis in bacteria, regulation and production perspectives
}

\author{
María Elisa Pavan ${ }^{1}$ - Nancy I. López ${ }^{1,2} \cdot$ M. Julia Pettinari ${ }^{1,2}$ (D) \\ Received: 24 September 2019 / Revised: 25 October 2019 / Accepted: 4 November 2019 / Published online: 7 December 2019 \\ (C) Springer-Verlag GmbH Germany, part of Springer Nature 2019
}

\begin{abstract}
The production of black pigments in bacteria was discovered more than a century ago and related to tyrosine metabolism. However, their diverse biological roles and the control of melanin synthesis in different bacteria have only recently been investigated. The broad distribution of these pigments suggests that they have an important role in a variety of organisms. Melanins protect microorganisms from many environmental stress conditions, ranging from ultraviolet radiation and toxic heavy metals to oxidative stress. Melanins can also affect bacterial interactions with other organisms and are important in pathogenesis and survival in many environments. Bacteria produce several types of melanin through dedicated pathways or as a result of enzymatic imbalances in altered metabolic routes. The control of the melanin synthesis in bacteria involves metabolic and transcriptional regulation, but many aspects remain still largely unknown. The diverse properties of melanins have spurred a large number of applications, and recent efforts have been done to produce the pigment at biotechnologically relevant scales.
\end{abstract}

Keywords Melanin $\cdot$ Biopolymer $\cdot$ Biomaterial $\cdot$ L-DOPA $\cdot$ Homogentisate $\cdot$ Melanin synthesis control $\cdot$ Stress protection

\section{Introduction}

The production of dark bacterial pigments related to tyrosine metabolism was discovered more than a century ago (Beijerinck 1900; Beijerinck 1911; Skinner 1938), but many aspects have not yet been completely elucidated. The term "melaina" (from Greek $\mu \varepsilon \dot{\lambda} \alpha \alpha_{\varsigma}$ black and $\alpha \dot{\varepsilon}$ al always, meaning "always black matter"), from which the word melanin derives, was first coined by Bizio ${ }^{1}$ to name the black matter he extract-

\footnotetext{
${ }^{1}$ Bartolomeo Bizio was an Italian scientist, one of the precursors of modern microbiology though little is known about him at present. He chemically analyzed the ink of Sepia that he considered of a unique and admirable black color. In words of Bizio "having obtained a black matter so pure and so special that it cannot be compared with any of the known substances, I felt compelled to call it with a name that belonged only to it, naming her melaina" (Bizio 1825).

Nancy I. López

nan@qb.fcen.uba.ar

$\triangle$ M. Julia Pettinari jul@qb.fcen.uba.ar

1 Departamento de Química Biológica, Facultad de Ciencias Exactas y Naturales, Universidad de Buenos Aires, Buenos Aires, Argentina

2 IQUIBICEN-CONICET, Facultad de Ciencias Exactas y Naturales, Universidad de Buenos Aires, Buenos Aires, Argentina
}

ed from the ink of the cuttlefish Sepia (Bizio 1825; Berzelius 1840). Melanins are heterogeneous pigments formed by the oxidative polymerization of indolic or phenolic compounds, found in many animals, plants, and some fungi and bacteria (Solano 2014; Toledo et al. 2017). The broad distribution of melanins suggests that they have an important role in many organisms. These biopolymers are classified into different types taking into account their chemical nature, the synthesis pathways, and the particular enzymes involved. Studies performed in recent years dealing both with the remarkable properties of melanins and their functions in diverse environments inspire innovative applications, such as the development of functionalized biomaterials, by combining melanin with metals or other biopolymers. Development of processes to produce environmentally friendly and cost-effective melanins using microorganisms would pave the way for future applications for these interesting pigments.

The general aspects of melanin chemical nature and biosynthesis have been reviewed by Plonka and Grabacka (2006) and Solano (2014). This review will focus on the biosynthesis of bacterial melanins with emphasis on regulatory aspects, the role of these polymers on bacterial ecology and physiology, and the biotechnological production of these pigments. 


\section{Chemical characterization of bacterial melanins}

Melanins are formed through the oxidation of hydroxylated aromatic compounds giving rise to reactive quinones that then polymerize forming these heteropolymeric pigments in the presence of oxygen (Fig. 1). Tests used to determine whether black-brown pigments produced by microorganisms are melanins take into account their insolubility in most organic solvents and water, bleaching by oxidizing agents and precipitation with ferric chloride (Sajjan et al. 2010; Mekala et al. 2019). Melanins cannot be described in terms of a single well-defined structure and their poor solubility severely limits the range of techniques that can be used to determine their chemical characteristics.

Melanins are routinely analyzed by UV-visible and IR spectroscopy. All types of melanin have similar UV-visible spectra with highest absorption at the UV region of 200 to $350 \mathrm{~nm}$, with a continuous decrease in the absorbance towards the visible region (Mekala et al. 2019). This conserved characteristic is attributed to the complex structure of melanins (Tarangini and Mishra 2013). As the decrease in the absorption with increasing wavelength is almost linear for melanins, the slope of log absorbance versus wavelength from 400 to $600 \mathrm{~nm}$ was recently used to identify these pigments (Manivasagan et al. 2013; Li et al. 2018). Characterization of melanins through FTIR (Fourier transform infrared) spectroscopy provides information on functional groups, revealing strong similarities between different kinds of natural melanins and synthetic DOPA melanin (Sajjan et al. 2010; Drewnowska et al. 2015; Mekala et al. 2019). Other specific additional analysis can be performed to obtain a more exhaustive characterization of the polymer (Gómez-Marín and Sánchez 2010; Ganesh et al. 2013; Guo et al. 2014; Banerjee et al. 2014; ElNaggar and El-Ewasy 2017).

\section{Melanin biosynthesis}

Most bacterial melanins are formed due to transformations of aromatic amino acids such as tyrosine. Additionally, some bacteria can produce melanin from malonyl-CoA in a process catalyzed by polyketide synthases (Fig. 1).

Melanin synthesis through type III polyketide synthases was thought to be exclusive to plants until it was described in Streptomyces griseus in 1999 (Funa et al. 1999). This pathway involves the sequential decarboxylative condensation of five molecules of malonyl-coenzyme A catalyzed by the homodimeric type III polyketide synthase RppA leading to the synthesis of 1,3,6,8-tetrahydroxynaphthalene (THN). A member of the cytochrome P450 family co-transcribed with rppA catalyzes the oxidative dimerization of two THN subunits to yield hexahydroxyperylenequinone (HPQ) (Funa et al. 2005). The autopolymerization of this unstable precursor leads to the formation of brownish HPQ melanin (Fig. 1).

The most widespread pathways for melanin synthesis in bacteria involve melanin precursors derived from tyrosine transformations. This monohydroxylated compound is oxidized to yield dihydroxylated (diphenol) derivatives through reactions in which the amino group can be conserved, giving

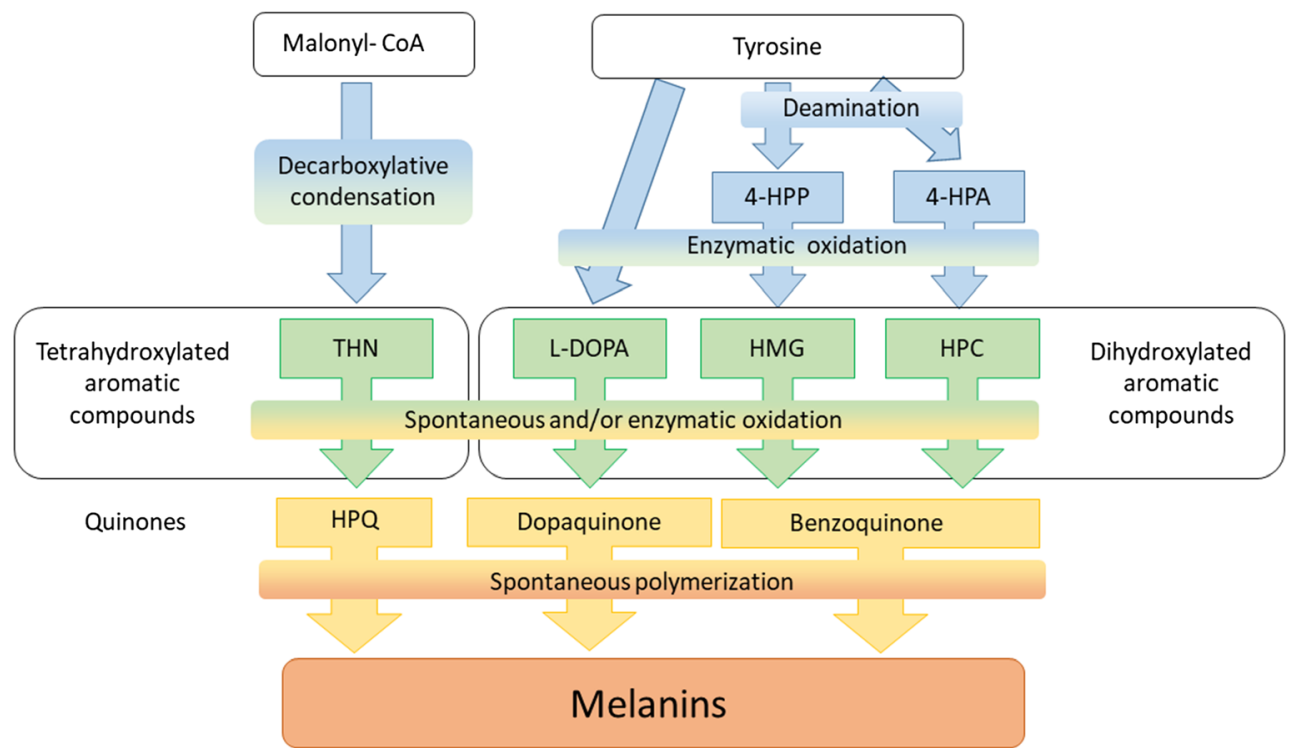

Fig. 1 Schematic representation of melanin production in bacteria, indicating key chemical transformations common to bacterial melanin forming processes. Malonyl-CoA and tyrosine, the two compounds shown at the top, are involved in different melanin biosynthesis pathways. 4-HPA, 4-hydroxyphenylacetate; 4-HPP, 4- hydroxyphenylpyruvate; THN, 1,3,6,8-tetrahydroxynaphthalene; LDOPA, L-3,4-dihydroxyphenylalanine; HMG, homogentisate $(2,5$ hydroxyphenylacetate); HPC, homoprotocatechuate $(3,4$ hydroxyphenylacetate); HPQ, 1,4,6,7,9,12-hexahydroxyperylene-3,10quinone 
rise to L-DOPA (L-3,4-dihydroxyphenylalanine), or eliminated prior to oxidation, generating compounds such as homogentisate (2,5-dihydroxyphenylacetate) or homoprotocatechuate (3,4-dihydroxyphenylacetate). These compounds are oxidized spontaneously or through the activity of specific enzymes giving rise to dopaquinones or benzoquinones. Melanins are the result of the autopolymerization of these quinones (Fig. 1).

DOPA melanins are synthesized by tyrosinases and laccases. The tyrosinases (EC 1.14.18.1) are bifunctional copper containing polyphenol oxidases that catalyze the hydroxylation of tyrosine to L-DOPA and its subsequent oxidation to $o$-dopaquinone (Claus and Decker 2006) (Fig. 1). This quinone suffers spontaneous cyclization to indole quinone, and finally, this compound or its carboxylated form spontaneously polymerize to form brown to black DOPA melanins, also known as eumelanins (Plonka and Grabacka 2006). In the presence of cysteine, L-DOPA can undergo cysteinylation prior to polymerization, originating yellow to red sulfur containing melanins (Zaidi et al. 2014).

Tyrosinases are widely distributed in nature and can have monophenol and $o$-diphenol substrate specificities (Faccio et al. 2012; Fairhead and Thöny-Meyer 2012). Tyrosinases related to melanin synthesis in bacteria were initially studied in Streptomyces (Lerch and Ettinger 1972), in which they are encoded by the bicistronic operon melC. The tyrosinase $\mathrm{MelC} 2$ remains inactive until it is secreted and activated with the help of MelC1 that acts as a chaperone for secretion and copper incorporation into the tyrosinase active site (Leu et al. 1992). The tyrosinase, that lacks any signal peptide, is exported through the general twin-arginine translocation (Tat) pathway as a complex with MelC1, which has a typical Tat-targeting signal (Schaerlaekens et al. 2001). After transport, $\mathrm{MelC} 1$ dissociates from the tyrosinase. Both dissociation and tyrosinase activation depend on the presence of copper in the medium (Chen et al. 1992; Tsai and Lee 1998). The first crystal structure resolved of a tyrosinase was that of the Streptomyces castaneoglobisporus, revealing that the enzyme dinuclear $\mathrm{Cu}$ center is flexible and that this flexibility is important for its catalytic specificity (Matoba et al. 2006). Tyrosinases involved in the synthesis of melanin are present in Gram-positive and Gram-negative bacteria, such as Sinorhizobium meliloti (Mercado-Blanco et al. 1993), Ralstonia solanacearum (Hernández-Romero et al. 2005), Marinomonas mediterranea (López-Serrano et al. 2004; Solano et al. 2000), Pseudomonas putida (McMahon et al. 2007), Vibrio tyrosinaticus (Pomerantz and Murthy 1974), Vibrio nigripulchritudo (Goudenège et al. 2013), Saccharophagus degradans (Kelley et al. 1990; Ekborg et al. 2005), Bacillus thuringiensis (Liu et al. 2004), Bacillus megaterium (Shuster and Fishman 2009), and Bacillus licheniformis (Gamal Shalaby et al. 2019). Bacterial tyrosinases were reviewed by Claus and Decker (2006), Sanchez-
Amat et al. (2010), Faccio et al. (2012), and Fairhead and Thöny-Meyer (2012).

Another type of polyphenol oxidases involved in melanin synthesis are laccases (EC 1.10.3.2). These enzymes lack monophenol hydroxylase activity, but oxidize a variety of diphenols (Sanchez-Amat et al. 2010; Reiss et al. 2011). Just like tyrosinases, laccases have copper ions bound to conserved histidine residues in the active site (Shuster and Fishman 2009; Singh et al. 2013). Laccases from plants and fungi are frequent and well known, and their bacterial counterparts have been the subject of recent studies (Singh et al. 2011; Chauhan et al. 2017; Unuofin et al. 2019). Laccases involved in the synthesis of melanin are present in Azospirillum lipoferum (Givaudan et al. 1993; Diamantidis et al. 2000), S. meliloti (Castro-Sowinski et al. 2002), Bacillus subtilis (Hullo et al. 2001), and Bacillus weihenstephanensis (Drewnowska et al. 2015). In some bacteria, tyrosinases and laccases activities coexist, as in Pseudomonas putida F6 (McMahon et al. 2007), Alteromonas sp. (Sanchez-Amat and Solano 1997), and Bacillus sp. (Dalfard et al. 2006). The production of another kind of melanin synthesized by polyphenol oxidases from catechol in some strains of Azotobacter chroococcum has been proposed to occur in nitrogen fixing conditions in the presence of oxygen (Shivprasad and Page 1989; Herter et al. 2011).

Originally, synthesis of melanin in bacteria was thought to occur only through the DOPA pathway. In 1972, a brown pigment derived from homogentisate was described in Pseudomonas aeruginosa and was called pyomelanin (Yabuuchi and Ohyama 1972). Two decades later, it was found that the 4-hydroxyphenylpyruvate dioxygenase directed the production of a pigment derived from homogentisate in Streptomyces avermitilis (Denoya et al. 1994). This kind of pigment was known to be produced from oxidative degradation of tyrosine and found in the urine of alkaptonuric patients. In fact, alkaptonuria was the first human disorder, described by Garrod in 1902, found to conform the principles of the Mendelian recessive inheritance (Garrod 1996; Mistry et al. 2013). Although the homogentisate pathway is common to virtually all forms of life, from animals and plants to fungi and bacteria, it does not occur in the model organism E. coli (McFall and Newman 1996) and was largely overlooked in bacteria until recent studies performed mostly in Pseudomonas (Arias-Barrau et al. 2004; Rodríguez-Rojas et al. 2009).

In the homogentisate pathway, tyrosine is catabolized in five successive steps. First, tyrosine is deaminated into 4-hydroxyphenylpyruvate by aromatic amino acid aminotransferases. The 4-hydroxyphenylpyruvate dioxygenase (EC 1.13.11.27) acts on this compound to generate homogentisate in a complex reaction that involves oxygen addition, decarboxylation, and rearrangement of the side chain on the aromatic ring (He and Moran 2009). 
Homogentisate is then degraded by the homogentisate 1,2-dioxygenase and successive enzymes with fumarate and acetoacetate as final products. The accumulation, spontaneous autooxidation, and polymerization of homogentisate lead to the synthesis of melanin (Fig. 1). This accumulation can be due to the absence or inactivation of the homogentisate 1,2-dioxygenase or to increased 4-hydroxyphenylpyruvate dioxygenase activity. Melaninproducing Aeromonas contain different mutations in the homogentisate 1,2-dioxygenase gene ( $h m g A)$. For example, in A. salmonicida A449, hmgA is a pseudogene, while in A. salmonicida subsp. pectinolytica $34 \mathrm{mel}^{\mathrm{T}}$ and A. media WS, this gene is interrupted by transposases (Pavan et al. 2015; Wang et al. 2015). In contrast, Vibrio cholerae HTX-3, Shewanella colwelliana D, and a strain of Hyphomonas accumulate homogentisate due to increased amounts of the 4-hydroxyphenylpyruvate dioxygenase and not to a mutation in $h m g A$ (Kotob et al. 1995). Additionally, homogentisate accumulation and melanin formation was observed in $V$. cholerae strains that display a 15-bp deletion in $h m g A$ (Wang et al. 2011), and a single amino acid substitution (G378R) in the homogentisate 1,2-dioxygenase is responsible for pigmentation in Burkholderia cepacia complex isolates (Gonyar et al. 2015). Transposon insertions in $h m g A$ also resulted in accumulation of homogentisate and production of melanin in clinical isolates of Pseudomonas aeruginosa (Rodríguez-Rojas et al. 2009). In the photosynthetic Rubrivivax benzoatilyticus, accumulation of melanin was found to be due to the absence of $h m g A$ (Mekala et al. 2019). Other bacterial genera with some strains capable of producing homogentisate melanins are Xanthomonas campestris pv. phaseoli (Goodwin and Sopher 1994), Klebsiella pneumoniae, Alcaligenes faecalis, and Enterobacter sp. (Singh et al. 2018).

Another pathway reported for the synthesis of tyrosinederived melanins involves the oxidation and polymerization of homoprotocatechuate, an isomer of homogentisate (Fig. 1).
The formation of a dark brown pigment in Serratia marcescens was attributed to the 4-hydroxyphenylacetate 3monooxygenase activity (EC 1.14.14.9). This enzyme can catalyze the hydroxylation of 4-hydroxyphenylacetate to 3,4dihydroxyphenylacetate (homoprotocatechuate), so it has been proposed that pigment formation was related to accumulation of this compound (Trias et al. 1989; Gibello et al. 1995). However, this enzyme that catalyzes the oxidation of dihydroxylated aromatic compounds giving rise to quinones has relaxed enzyme specificity (Gibello et al. 1997), and the chemical nature of the pigment formed in $S$. marcescens could not be determined, so it cannot be ruled out that it could arise from the oxidation of other dihydroxylated compounds.

\section{Control of melanin synthesis in bacteria}

There are many different pathways for melanin synthesis, but all involve the oxidation of hydroxylated aromatic compounds. Some of these compounds are synthesized by tyrosinases, laccases, or polyketide synthases in dedicated biosynthetic pathways, subject to specific regulation. Other hydroxylated aromatic compounds are intermediates in catabolic pathways, such as the degradation of tyrosine, and can accumulate as a result of imbalances or interruptions in the degradation pathways (Fig. 2).

In bacteria that produce melanin through the oxidation of L-DOPA, pigment formation is linked to the regulation of enzyme synthesis driven by nutrient factors such as the presence of $\mathrm{Cu}$, nitrogen sources, and oxygen availability, but also by general regulatory networks, like those that control cellular processes such as nitrogen fixation, stress responses, or morphogenesis.

Melanin formation has been extensively studied in rhizobacteria, in which pigmentation was observed to depend on multiple nutritional factors. For example, in Rhizobium leguminosarum bv. phaseoli, in which melanin-related genes are found in the symbiosis plasmid, melanin is formed in rich
Fig. 2 Simplified pathways of tyrosine-derived melanin synthesis showing enzymatic steps subject to regulation. LDOPA, L-3,4-

dihydroxyphenylalanine; 4-HPP, 4-hydroxyphenylpyruvate; Hpd, 4-hydroxyphenylpyruvate dioxygenase; HmgA, homogentisate 1,2-dioxygenase

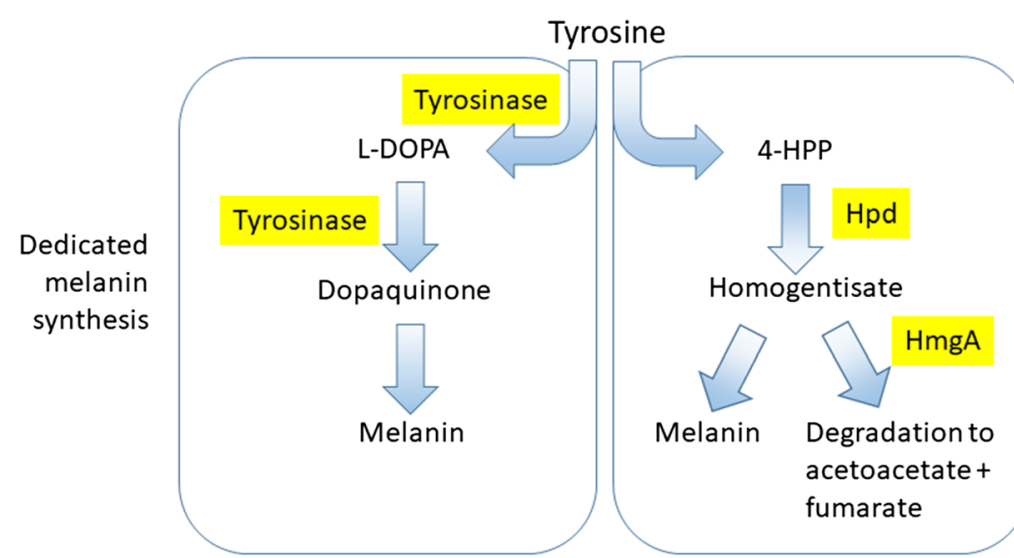

Imbalances in tyrosine utilization via homogentisate 
medium but not in minimal medium even when both tyrosine and $\mathrm{Cu}$ are added (Borthakur et al. 1987). Regulation of melanin synthesis in this microorganism depends on the regulator of nitrogen fixation NifA that activates the transcription of the tyrosinase coding gene, especially at low oxygen availability (Hawkins and Johnston 1988). A study of melanin-deficient Sinorhizobium meliloti transposon mutants revealed a relationship between a thioredoxin and melanin production. The gene coding for the thioredoxin $(\operatorname{tr} x L)$ is induced in melaninproducing conditions, and trx $L$ mutants are unable to produce pigment due to a greatly diminished tyrosinase activity (Castro-Sowinski et al. 2007). The thioredoxin also affects nitrogen fixation, and it has been proposed to modulate the redox potential (Castro-Sowinski et al. 2007), providing a possible link between oxygen availability, nitrogen fixation, and melanin production in S. meliloti.

The presence of some amino acids, and particularly methionine, was observed to increase the transcription of the tyrosinase gene in several Streptomyces (Crameri et al. 1982; Ikeda et al. 1996; Katz and Betancourt 1988). Interestingly, tyrosine, the tyrosinase substrate, was not observed to increase its activity, and in S. castaneoglobisporus even had small inhibitory effect on tyrosinase activity (Ikeda et al. 1996). In Streptomyces michiganensis, supplementation of the medium with ammonium, but not other nitrogen sources such as $\mathrm{KNO}_{3}$, urea, or amino acids, inhibited tyrosinase formation at the transcriptional level (Held and Kutzner 1990). The role of $\mathrm{Cu}$ in melanization has been extensively studied in Streptomyces, in which it is necessary for tyrosinase activity and increases the transcription of the corresponding gene (Held and Kutzner 1990). Although $\mathrm{Cu}$ has been observed to enhance melanin formation in most cases, other metals can have a similar effect. A recent detailed analysis of nutritional factors that affect pigmentation in a Streptomyces isolate reported that peptone, but not tyrosine, increased tyrosinase activity, and that the addition of $\mathrm{Fe}$ and $\mathrm{Ni}$ have a strong enhancing effect on tyrosinase expression and melanin production (Wang et al. 2019).

In some cases, melanin formation is induced by different kinds of stress. Pigmentation is induced by stress conditions in M. mediterranea, such as those encountered when they reach the stationary phase, suggesting that melanin synthesis could be part of the adaptive response in this microorganism (LucasElío et al. 2002). In Azospirillum, exposure to Zn triggers pigment production followed by encystation (Gowri and Srivastava 1996). The induction of melanin formation at high temperatures was observed in B. thuringiensis (Ruan et al. 2004), that produces a thermostable tyrosinase (Liu et al. 2004).

In several Streptomyces species, tyrosinase expression is activated by the transcriptional regulator AdpA, that controls morphological development in response to A factor levels (Zhu et al. 2005). AdpA also regulates the synthesis of the type III polyketide synthase RppA, responsible for HPQ melanin formation. This transcriptional regulator, along with the stress response sigma factors, activates the transcription of rppA, and of many genes required for both morphological development and secondary metabolism (Takano et al. 2007). These results show a clear regulatory link between pigment formation and other processes such as sporulation in these physiologically and morphologically complex bacteria.

Unlike the cases in which melanins are synthesized by dedicated biosynthetic pathways, melanin formation from degradation intermediates such as homogentisate depends on the accumulation of these compounds due to alterations in the corresponding degradation routes (Fig. 2). The homogentisate pathway involves enzymes that lead to the formation of 4-hydroxyphenylpyruvate (4-HPP) from phenylalanine (PhhA and $\mathrm{PhhB}$ ), or tyrosine (PhhC/TyrB) followed by the conversion of 4-HPP to homogentisate (catalyzed by Hpd), that is further degraded by HmgA to acetoacetate and fumarate. The transcription of the corresponding genes is normally controlled by the concentration of aromatic amino acids. In Pseudomonas, the transcriptional regulator PhhR activates $p h h A, h p d$, and $h m g A$ in the presence of phenylalanine or tyrosine (Herrera et al. 2009; Palmer et al. 2010), while HmgR represses $h m g A$ in P. putida (Arias-Barrau et al. 2004). An in silico study has proposed that HmgR could also control hpd in Shewanella (Stepanova and Rodionov 2011), while in $S$. meliloti $h p d$ is activated by the specific regulator HpdR (Loprasert et al. 2007).

Accumulation of homogentisate can be caused by an increase in the expression of $\mathrm{Hpd}$, that converts 4hydroxyphenylpyruvate to homogentisate (Kotob et al. 1995), by the absence of HmgA (Mistry et al. 2013), the enzyme that leads to homogentisate degradation, or by a decreased activity of this last enzyme (Sanchez-Amat et al. 1998) (Fig. 2). Differences in the expression of the genes that code for these enzymes indicate that other factors, apart from aromatic amino acid availability, can affect their synthesis. Mutant studies performed in A. media, P. aeruginosa, and $R$. solanacearum have revealed that many genes, including several transcriptional regulators and transport proteins that are not directly involved in the formation or degradation of homogentisate, can affect melanin biosynthesis (Hunter and Newman 2010; Wang et al. 2015; Ahmad et al. 2016). Nutritional factors, but also physicochemical conditions and growth mode, can affect melanization. In A. salmonicida subsp. pectinolytica, the presence of glycerol was observed to abolish melanin synthesis through a combination of metabolic and regulatory effects, including the generation of a more reduced environment, unfavorable for homogentisate oxidation, and a significant inhibition of $h p d$ transcription (Pavan et al. 2019). 
High temperature and biofilm formation promoted melanin synthesis in Pseudoalteromonas, since these conditions induced the synthesis of the enzyme leading to homogentisate formation more than the one leading to its degradation, resulting in pigment formation (Zeng et al. 2017a). In $V$. cholerae, hyperosmotic stress and high temperatures increased melanin formation, especially in nutrient poor growth media (Coyne and Al-Harthi 1992), and in Vibrio anguillarum, a Lux-R like transcriptional regulator controls biofilm formation and pigment production (Croxatto et al. 2002), providing further evidence of the relationship between biofilm and melanin formation. In $R$. solanacearum that produces melanin in stationary phase when grown in minimal medium with tyrosine, several transcriptional regulators were shown to control melanin production. While OxyR, RpoS, and $\mathrm{HrpG}$, involved in the regulation of stress response and pathogenicity, are essential for melanin synthesis (Ahmad et al. 2016), another transcription factor represses pigment formation in this microorganism (Ahmad et al. 2017). Factors that affect melanin synthesis are multiple and diverse, as shown by a recent study in which a $P$. aeruginosa transcription factor expressed in response to exposure to surface acoustic waves increased melanin formation through an unknown mechanism (Ben-David et al. 2018).

The diversity of melanin synthesis pathways and factors that affect pigmentation shows that this process is subject to several types of control, even in bacteria that produce the pigment through an apparently non-dedicated pathway. In spite of differences observed in the factors that affect melanization in different organisms, in most bacteria, both the presence of tyrosine and $\mathrm{Cu}$ have been observed to enhance melanogenesis. In the case of DOPA melanins, this effect can be obviously attributed to the fact that tyrosinases contain this metal in their structure. However, the underlying causes of the enhancing effect of $\mathrm{Cu}$ on melanogenesis is not straightforward in the case of bacteria that accumulate other melanins that do not involve tyrosinases or other known Cu-containing enzymes.

\section{Ecological and physiological role of bacterial melanins}

Melanins can have a wide variety of functions in different bacteria. In both pathogenic and environmental bacteria, melanins confer adaptive advantages, increasing fitness and survival in many stress conditions (Fig. 3).

The relationship between melanin synthesis and the increase of virulence has been extensively reported in bacterial pathogens (Nosanchuk and Casadevall 2003; Plonka and Grabacka 2006). Melanin can increase microbial virulence through two mechanisms: it reduces the susceptibility of the pathogen to host defense mechanisms and affects the host immune response to infection (Nosanchuk and Casadevall 2006). In melanogenic $V$. cholerae, pigment production increases cholera toxin and pilus expression, and enhances host colonization (Valeru et al. 2009). Due to its free radical scavenging potential, melanin can diminish host cell oxidative burst as observed in some melanin producing epidemic strains of $B$. cenocepacia, protecting this pathogen from oxidative stress (Keith et al. 2007). This trait was also observed for the plant pathogen $R$. solanacearum, and it has been suggested that protection against oxidative stress could help the bacteria cope with plant defense mechanisms (Ahmad et al. 2016). In Legionella pneumophila, melanin is involved in the increase of iron bioavailability through the reduction of ferric to ferrous form, stimulating bacterial growth under iron-limited conditions such as those encountered in mammalian hosts and natural environments (Zheng et al. 2013). During chronic $P$. aeruginosa infections in humans, melanin producers emerge spontaneously due to deletions in a genomic region containing $h m g A$. This phenomenon that leads to mixed populations of pigmented and non-pigmented bacteria in continuous evolution has been attributed to selective pressure exerted by intraspecific competition (Hocquet et al. 2016).

In non-pathogenic bacteria, melanin is related to several biological interkingdom interactions (Fig. 3). During symbiosis of Rhizobium etli, tyrosinase activity, and consequently melanin production, is necessary during the first stages of nodulation, when bacteria need to cope with reactive oxygen species (ROS) and phenolic compounds derived from plant defenses (Piñero et al. 2007). Melanin is also involved in interactions between bacterial biofilms and other organisms. The biofilms of the marine bacterium Pseudoalteromonas lipolytica secrete melanin that inhibits the larval settlement and metamorphosis of mussels leading to reduced biofouling activity (Zeng et al. 2017b). Melanin production in V. cholerae biofilms increases ROS production, protecting this microorganism against amoeba predation (Noorian et al. 2017).

One of the major roles traditionally attributed to melanins is their capability to protect cells from UV radiation. In Bacillus anthracis, pigmented mutants are more resistant to UV exposure (Han et al. 2015), and melanized spores of S. griseus are more resistant to UV irradiation than colorless mutants (Funa et al. 2005). In addition, melanogenic $P$. aeruginosa strains are more tolerant to photodynamically induced oxidative stress (Orlandi et al. 2015). While bacterial melanin protects the producing organisms from photodamage, this protection can be extended to other organisms living in close association. For example, the dark pigmentation of sponges that contain Vibrio, Providencia, and Shewanella symbionts is due to melanins secreted by these melanogenic microorganisms that protect sponge cells from photodamage (Vijayan et al. 2017). The fact that several non-phylogenetically related bacteria sharing the same ecological niche produce melanins suggests that these pigments have an important role in nature. 
Fig. 3 Ecological and physiological role of melanin and derived applications

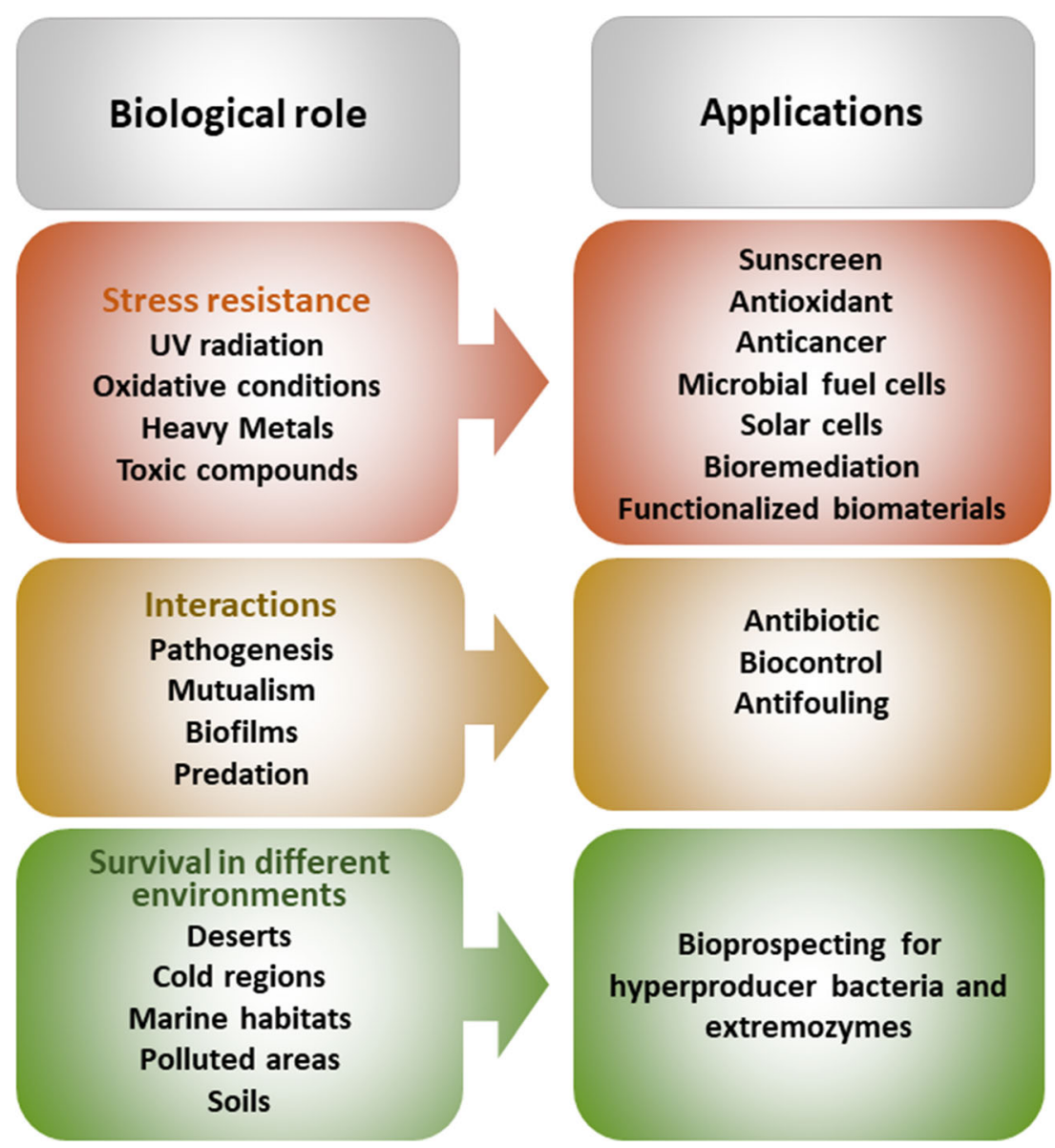

Melanin production can also provide selective advantages for the survival in many environments, in some cases by enhancing the capability to respond to rapidly changing environmental conditions. Melanogenic members of Shewanella can span from anoxic to highly oxygenated zones. In these bacteria, melanin can be utilized as terminal electron acceptor for anaerobic respiration and also as electron shuttle during respiration of $\mathrm{Fe}(\mathrm{III})$ minerals when oxygen concentration declines, thus conferring a competitive advantage by enhancing respiratory versatility (Turick et al. 2002; Turick et al. 2009).

Melanogenic bacteria have also been found in extreme environments. Some examples are Streptomyces cyaneofuscatus, that has a highly thermoresistant tyrosinase, isolated from the Sahara desert (Harir et al. 2018), the psychrotolerant melanin producer $B$. weihenstephanensis isolated from cold environments in Poland (Drewnowska et al. 2015), or Lysobacter oligotrophicus, a bacterium able to increase melanin production after UV exposure, isolated in Antarctica (Kimura et al. 2015). Highly contaminated areas are also extreme environments where microorganisms have to thrive under harsh conditions of anthropogenic origin such as those containing nuclear waste, heavy metals, or oil spills. Melanin production in A. salmonicida subsp. pectinolytica, isolated from a heavily polluted river (Pavan et al. 2000), has been proposed to help this extremophile cope with the high concentrations of heavy metals, hydrocarbons, and other pollutants found in this environment (Pavan et al. 2015).

\section{Biotechnological applications}

The diverse and unusual properties of melanins make them useful for a variety of applications (Fig. 3). Due to its photoprotective, antioxidant, and antimicrobial features, melanin can have cosmetic and pharmaceutical uses. For example, melanin produced by Pseudomonas stutzeri was used to increase the sun protection factor of commercial sunscreens (Kurian and Bhat 2018). In addition, these pigments might have clinical and agricultural applications. Melanin obtained from Pseudomonas balearica, isolated from a marine green alga, has been proposed as a biocontrol agent because of its antimicrobial activity against Staphylococcus aureus, E. coli, Candida albicans, and the phytopathogenic Erwinia (Zerrad et al. 2014). Another interesting application concerns the insecticidal crystal proteins produced by B. thuringiensis. A melanin producer mutant of this bacterium protected the protein from UV radiation damage, indicating that it could be 
useful for the industrial production of light-stable environmentally friendly insecticides (Liu et al. 2013).

Melanogenic bacteria can be used for bioremediation purposes due to the metal affinity and high adsorption capacity of melanins. For example, in situ stimulation of melanin synthesis by indigenous microbes through addition of tyrosine increased uranium immobilization in contaminated soils (Turick et al. 2008). Different studies proposed the detoxification of soils or waters polluted with heavy metals by melanin producing microorganisms as A. chroococcum (Rizvi et al. 2019) or by melanin nanoparticles produced by P. stutzeri (Thaira et al. 2019; Manirethan et al. 2018), during environmental management. A recombinant $E$. coli with membrane bound tyrosinase, that resulted in the formation of an outer melanin layer, was used for the bioremediation of drug pollution in wastewaters in a bioreactor assay, and the melanin could be regenerated after chemical compounds adsorption (Gustavsson et al. 2016).

In addition, melanins are considered disordered organic conductors, with unique physical and chemical properties, with the potential to be used in different technological applications (Gómez-Marín and Sánchez 2010). The ability of melanin to function as an electron shuttle from the cell to iron minerals in Shewanella oneidensis allows electron transfer to electrodes, enhancing electricity production in microbial fuel cells (Turick et al. 2010).

Some recent studies reveal the potential of melanins in innovative nanotechnology applications: the synthesis of crystalline, flexible, and thermostable nanomelaninpolyhydroxybutyrate nanocomposite films for use in biomedicine or as packaging material (Kiran et al. 2017); the environmentally gentle synthesis and/or stabilization of $\mathrm{Ag}, \mathrm{Au}$, $\mathrm{Pt}, \mathrm{Cu}, \mathrm{Mn}$, and $\mathrm{Ni}$ nanoparticles mediated by melanins from Nocardiopsis alba or recombinant E. coli (Kiran et al. 2014; Tsai et al. 2014). Another recent study proposed the use of melanin from the Antarctic Streptomyces fildesensi as an environmentally friendly sensitizer pigment in dye sensitized solar cells (Silva et al. 2019).

\section{Bioproduction}

Microorganisms could be used to produce melanin at an industrial scale in environmentally friendly, economically feasible processes. Several studies have analyzed the potential of native and recombinant bacteria for the production of melanin, focusing on optimization of bacterial production, processes, or melanin purification (Table 1).

A high melanin yield was obtained from Streptomyces kathirae SC-1. Addition of yeast extract and $\mathrm{Cu}$ ions maximized production and $13.7 \mathrm{~g} \mathrm{l}^{-1}$ melanin could be obtained after optimization, indicating that this microorganism could be a good candidate for industrial-scale production (Guo et al. 2014) (Table 1). Melanin production was doubled when the
melC operon of $S$. kathirae, encoding the chaperone MelC1 and the tyrosinase $\mathrm{MelC} 2$, was cloned with its own promoter and overexpressed in the same microorganism (Guo et al. 2015). An optimized medium supplemented with tyrosine and $\mathrm{Cu}$ was also used to increase melanin yield using Brevundimonas sp. SGJ (Surwase et al. 2013). To reduce melanin production costs, fruit waste extracts were used as economical carbon source using a soil isolate of Bacillus safensis (Tarangini and Mishra 2014).

Some strategies focused on the isolation of melanin producing bacteria from marine environments. Thus, Kiran et al. (2017) optimized melanin production using a strain of Pseudomonas isolated from a marine sponge. The melanin obtained was readily soluble in hexane, DMSO, and water at $\mathrm{pH}$ above 7 , and used to develop nanomelanin particles used to synthetize non-toxic nanomelanin-PHB (polyhydroxybutyrate) nanocomposite films. Pseudomonas stutzeri HMGM-7, isolated from the surface of a red seaweed, was used to produce melanin in nutrient broth cultures prepared in sea-water and supplemented with tyrosine, and purified through an easy and inexpensive two-step procedure consisting of a simple acid precipitation followed by centrifugation (Ganesh Kumar et al. 2013).

Nocardiopsis alba MSA10 melanin, produced in sucrosecontaining culture medium, was used for the environmentally gentle synthesis of silver nanostructures. Melanin supernatants were first adjusted to $\mathrm{pH} 9$ with $\mathrm{NaOH}$ to ensure complete polymerization previous to acid precipitation. The purified melanin proved to be stable in a wide range of $\mathrm{pHs}$, temperatures up to $100{ }^{\circ} \mathrm{C}$ even for $3 \mathrm{~h}$, and different sources of light including UV (Kiran et al. 2014).

Studies involving other microorganisms, such as Actinoalloteichus sp. MA-32 (Manivasagan et al. 2013) or Streptomyces glaucescens NEAE-H (El-Naggar and El-Ewasy 2017), could not achieve melanin yields suitable for industrial production even after medium optimization (Table 1).

Production of melanin has also been studied in recombinant $E$. coli expressing an improved mutant version of the Rhizobium etli tyrosinase using two tyrosine feeding steps (Lagunas-Muñoz et al. 2006). A different strategy, that combined strain manipulation and process optimization, was to express this mutant tyrosinase in E. coli strains lacking the sugar phosphotransferase system and the repressor TyrR, with the idea to direct the carbon flow into the aromatic biosynthetic pathway in a strain that could produce melanin from glucose instead of tyrosine. The addition of $\mathrm{Cu}$ was delayed to control the activity of the tyrosinase to avoid bacterial growth problems due to the premature depletion of intracellular tyrosine (Chávez-Béjar et al. 2013).

The gene coding the 4-hydroxyphenylpyruvate dioxygenase of $P$. aeruginosa was also overexpressed in E. coli cells that gained the ability to produce homogentisate melanin although with poor yield (Bolognese et al. 2019). 


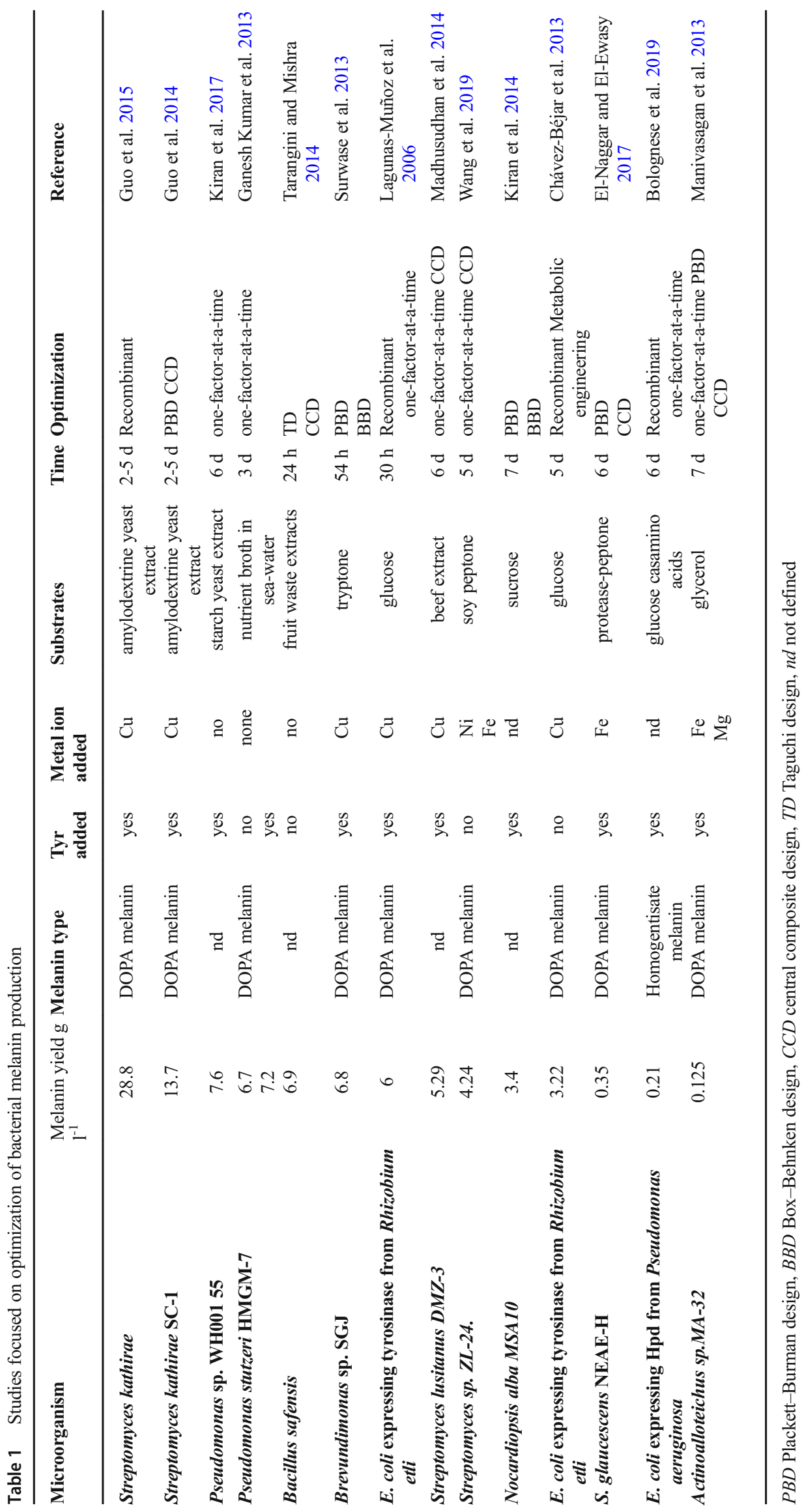


A recent report has described remarkable melanin production in bacteria isolated from sponges. Vibrio alginolyticus MMRF 534 and Vibrio harveyi MMRF 535 produce 50 and $40 \mathrm{~g}^{-1}$ melanin, respectively, in marine broth without optimization, suggesting that these organisms are very good potential candidates for industrial melanin production (Vijayan et al. 2017). These results suggest that bioprospecting for melanin producing bacteria, including those associated with other organisms or thriving in extreme environments, may be useful to find melanin hyperproducers or extremozymes that could enable higher melanin yields.

\section{Conclusions}

Melanins are complex biopolymers that attract great interest due to their unusual properties and diverse biological roles. Their production in bacteria spread among different taxonomic groups, including Gram positive and Gram negative. The ability to produce different types of melanin lies in dedicated biosynthetic pathways or in enzymatic imbalances in altered metabolic routes leading to accumulation of melanin precursors. Regulation of melanin biosynthesis in bacteria depends on global and specific regulators. Understanding melanin control mechanisms could contribute to improve bioprocesses leading to melanin production, but could also be used for the control of melanogenic pathogens. The remarkable properties of these biopolymers have inspired multiple and diverse applications. In an era marked by the search for sustainable biomaterials, multifunctional melanins have not yet reached their full potential.

Acknowledgments The authors thank Esteban Pavan for helpful comments. N.I.L. and M.J.P. are career investigators from CONICET.

Funding This work was partially supported by the University of Buenos Aires, CONICET, and Agencia Nacional de Promoción Científica y Tecnológica.

\section{Compliance with ethical standards}

Conflict of interest The authors declare that they have no conflict of interests.

Ethical approval This article does not contain any studies with human participants or animals performed by any of the authors.

\section{References}

Ahmad S, Lee SY, Kong HG, Jo EJ, Choi HK, Khan R, Lee SW (2016) Genetic determinants for pyomelanin production and its protective effect against oxidative stress in Ralstonia solanacearum. PLoS One 11:e0160845. https://doi.org/10.1371/journal.pone.0160845

Ahmad S, Lee SY, Khan R, Kong HG, Son GJ, Roy N, Choi K, Lee SW (2017) Identification of a gene involved in the negative regulation of pyomelanin production in Ralstonia solanacearum. J Microbiol Biotechnol 27:1692-1700. https://doi.org/10.4014/jmb.1705.05049

Arias-Barrau E, Olivera ER, Luengo JM, Fernández C, Galán B, García JL, Díaz E, Miñambres B (2004) The homogentisate pathway: a central catabolic pathway involved in the degradation of L-phenylalanine, L-tyrosine, and 3-hydroxyphenylacetate in Pseudomonas putida. J Bacteriol 186:5062-5077. https://doi.org/10.1128/JB.186. 15.5062-5077.2004

Banerjee A, Supakar S, Banerjee R (2014) Melanin from the nitrogenfixing bacterium Azotobacter chroococcum: a spectroscopic characterization. PLoS One 9:e84574. https://doi.org/10.1371/journal. pone. 0084574

Beijerinck MW (1900) Sur la production de quinone par le Streptothrix chromogena, et la biologie de ce microbe. In: Archives Néerlandaises des Sciences Exactes et Naturelles, Serie II, Tome III. Société hollandaise des sciences à Harlem, La Haye, pp 327 340. https://biodiversitylibrary.org/page/44932656

Beijerinck MW (1911) Pigments as products of oxidation by bacterial action. In: Proceedings of the Royal Netherlands Academy of Arts and Sciences (KNAW) 13 II, 1910-1911. Amsterdam, pp. 10661077

Ben-David Y, Zlotnik E, Zander I, Yerushalmi G, Shoshani S, Banin E (2018) SawR a new regulator controlling pyomelanin synthesis in Pseudomonas aeruginosa. Microbiol Res 206:91-98. https://doi. org/10.1016/j.micres.2017.10.004

Berzelius JJ (1840) Dinte vom Dintenfisch. In: Lehrbuch der Chemie, Vol 9. Arnoldischen Buchhandlung, Dresden-Leipzig, pp 776-778. h t t p s : / / b o o k s.google.com.a r/book s ? id= zp45AAAAcAAJ\&printsec=frontcover\#v=onepage \&q \&f=false

Bizio B (1825) Ricerche chimiche sovra l'inchiostro della Seppia. Giornale di fisica, chimica, storia naturale, medicina, ed Arti. Decade II, Tomo VIII: 88-108

Bolognese F, Scanferla C, Caruso E, Orlandi VT (2019) Bacterial melanin production by heterologous expression of 4hydroxyphenylpyruvate dioxygenase from Pseudomonas aeruginosa. Int J Biol Macromol 133:1072-1080. https://doi.org/ 10.1016/j.ijbiomac.2019.04.061

Borthakur D, Lamb JW, Johnston AW (1987) Identification of two classes of Rhizobium phaseoli genes required for melanin synthesis, one of which is required for nitrogen fixation and activates the transcription of the other. Mol Gen Genet 207:155-160. https://doi.org/10. 1007/bf00331503

Castro-Sowinski S, Martinez-Drets G, Okon Y (2002) Laccase activity in melanin-producing strains of Sinorhizobium meliloti. FEMS Microbiol Lett 209:119-125. https://doi.org/10.1111/j.1574-6968. 2002.tb11119.x

Castro-Sowinski S, Matan O, Bonafede P, Okon Y (2007) A thioredoxin of Sinorhizobium meliloti CE52G is required for melanin production and symbiotic nitrogen fixation. Mol Plant-Microbe Interact 20: 986-993. https://doi.org/10.1094/MPMI-20-8-0986

Chauhan PS, Goradia B, Saxena A (2017) Bacterial laccase: recent update on production, properties and industrial applications. 3 Biotech 7:323. https://doi.org/10.1007/s13205-017-0955-7

Chávez-Béjar MI, Balderas-Hernandez VE, Gutiérrez-Alejandre A, Martinez A, Bolívar F, Gosset G (2013) Metabolic engineering of Escherichia coli to optimize melanin synthesis from glucose. Microb Cell Factories 12:108. https://doi.org/10.1186/1475-285912-108

Chen LY, Leu WM, Wang KT, Lee YH (1992) Copper transfer and activation of the Streptomyces apotyrosinase are mediated through a complex formation between apotyrosinase and its trans-activator MelC1. J Biol Chem 267:20100-20107

Claus H, Decker H (2006) Bacterial tyrosinases. Syst Appl Microbiol 29: 3-14. https://doi.org/10.1016/j.syapm.2005.07.012

Coyne VE, Al-Harthi L (1992) Induction of melanin biosynthesis in Vibrio cholerae. Appl Environ Microbiol 58:2861-2865 
Crameri R, Ettlinger L, Hütter R, Lerch K, Suter MA, Vetterli JA (1982) Secretion of tyrosinase in Streptomyces glaucescens. J Gen Microbiol 128:371-379. https://doi.org/10.1099/00221287-128-2371

Croxatto A, Chalker VJ, Lauritz J, Jass J, Hardman A, Williams P, Cámara M, Milton DL (2002) VanT, a homologue of Vibrio harveyi LuxR, regulates serine, metalloprotease, pigment, and biofilm production in Vibrio anguillarum. J Bacteriol 184:1617-1629. https:// doi.org/10.1128/jb.184.6.1617-1629.2002

Dalfard AB, Khajeh K, Soudi MR, Naderi-Manesh H, Ranjbar B, Sajedi RH (2006) Isolation and biochemical characterization of laccase and tyrosinase activities in a novel melanogenic soil bacterium. Enzym Microb Technol 39:1409-1416

Denoya CD, Skinner DD, Morgenstern MR (1994) A Streptomyces avermitilis gene encoding a 4-hydroxyphenylpyruvic acid dioxygenase-like protein that directs the production of homogentisic acid and an ochronotic pigment in Escherichia coli. J Bacteriol 176: 5312-5319. https://doi.org/10.1128/jb.176.17.5312-5319.1994

Diamantidis G, Effosse A, Potier P, Bally R (2000) Purification and characterization of the first bacterial laccase in the rhizospheric bacterium Azospirillum lipoferum. Soil Biol Biochem 32:919-927. https://doi.org/10.1016/S0038-0717(99)00221-7

Drewnowska JM, Zambrzycka M, Kalska-Szostko B, Fiedoruk K, Swiecicka I (2015) Melanin-like pigment synthesis by soil Bacillus weihenstephanensis isolates from northeastern Poland. PLoS One 10:e0125428. https://doi.org/10.1371/journal.pone. 0125428

Ekborg NA, Gonzalez JM, Howard MB, Taylor LE, Hutcheson SW, Weiner RM (2005) Saccharophagus degradans gen. nov., sp. nov., a versatile marine degrader of complex polysaccharides. Int J Syst Evol Microbiol 55:1545-1549. https://doi.org/10.1099/ijs.0.636270

El-Naggar NE, El-Ewasy SM (2017) Bioproduction, characterization, anticancer and antioxidant activities of extracellular melanin pigment produced by newly isolated microbial cell factories Streptomyces glaucescens NEAE-H. Sci Rep 7:42129. https://doi. org/10.1038/srep42129

Faccio G, Kruus K, Saloheimo M, Thöny-Meyer L (2012) Bacterial tyrosinases and their applications. Process Biochem 47:1749-1760. https://doi.org/10.1016/j.procbio.2012.08.018

Fairhead M, Thöny-Meyer L (2012) Bacterial tyrosinases: old enzymes with new relevance to biotechnology. New Biotechnol 29:183-191. https://doi.org/10.1016/j.nbt.2011.05.007

Funa N, Ohnishi Y, Fujii I, Shibuya M, Ebizuka Y, Horinouchi S (1999) A new pathway for polyketide synthesis in microorganisms. Nature 400:897-899. https://doi.org/10.1038/23748

Funa N, Funabashi M, Ohnishi Y, Horinouchi S (2005) Biosynthesis of hexahydroxyperylenequinone melanin via oxidative aryl coupling by cytochrome P-450 in Streptomyces griseus. J Bacteriol 187: 8149-8155. https://doi.org/10.1128/JB.187.23.8149-8155.2005

Gamal Shalaby AS, Ragab TIM, Helal MMI, Esawy MA (2019) Optimization of Bacillus licheniformis MAL tyrosinase: in vitro anticancer activity for brown and black eumelanin. Heliyon 5:e01657. https://doi.org/10.1016/j.heliyon.2019.e01657

Ganesh Kumar C, Sahu N, Narender Reddy G, Prasad RB, Nagesh N, Kamal A (2013) Production of melanin pigment from Pseudomonas stutzeri isolated from red seaweed Hypnea musciformis. Lett Appl Microbiol 57:295-302. https://doi.org/10.1111/lam.12111

Garrod AE (1996) The incidence of alkaptonuria: a study in chemical individuality. 1902. Mol Med 2:274-282

Gibello A, Ferrer E, Sanz J, Martin M (1995) Polymer production by Klebsiella pneumoniae 4-hydroxyphenylacetic acid hydroxylase genes cloned in Escherichia coli. Appl Environ Microbiol 61: $4167-4171$

Gibello A, Suárez M, Allende JL, Martín M (1997) Molecular cloning and analysis of the genes encoding the 4-hydroxyphenylacetate hydroxylase from Klebsiella pneumoniae. Arch Microbiol 167: $160-166$

Givaudan A, Effosse A, Faure D, Potier P, Bouillant ML, Bally R (1993) Polyphenol oxidase in Azospirillum lipoferum isolated from rice rhizosphere: evidence for laccase activity in non-motile strains of Azospirillum lipoferum. FEMS Microbiol Lett 108:205-210. https:// doi.org/10.1111/j.1574-6968.1993.tb06100.x

Gómez-Marín AM, Sánchez CI (2010) Thermal and mass spectroscopic characterization of a sulphur-containing bacterial melanin from Bacillus subtilis. J Non-Cryst Solids 356:1576-1580. https://doi. org/10.1016/j.jnoncrysol.2010.05.054

Gonyar LA, Fankhauser SC, Goldberg JB (2015) Single amino acid substitution in homogentisate 1,2-dioxygenase is responsible for pigmentation in a subset of Burkholderia cepacia complex isolates. Environ Microbiol Rep 7:180-187. https://doi.org/10.1111/17582229.12217

Goodwin PH, Sopher CR (1994) Brown pigmentation of Xanthomonas campestris pv. phaseoli associated with homogentisic acid. Can J Microbiol 40:28-34

Goudenège D, Labreuche Y, Krin E, Ansquer D, Mangenot S, Calteau A, Médigue C, Mazel D, Polz MF, Le Roux F (2013) Comparative genomics of pathogenic lineages of Vibrio nigripulchritudo identifies virulence-associated traits. ISME J 7:1985-1996. https://doi. org/10.1038/ismej.2013.90

Gowri PM, Srivastava S (1996) Encapsulation as a response of Azospirillum brasilense sp7 to zinc stress. World J Microbiol Biotechnol 12:319-322. https://doi.org/10.1007/BF00340207

Guo J, Rao Z, Yang T, Man Z, Xu M, Zhang X (2014) High-level production of melanin by a novel isolate of Streptomyces kathirae. FEMS Microbiol Lett 357:85-91. https://doi.org/10.1111/15746968.12497

Guo J, Rao Z, Yang T, Man Z, Xu M, Zhang X, Yang ST (2015) Cloning and identification of a novel tyrosinase and its overexpression in Streptomyces kathirae SC-1 for enhancing melanin production. FEMS Microbiol Lett 362:fnv041. https://doi.org/10.1093/femsle/ fnv041

Gustavsson M, Hörnström D, Lundh S, Belotserkovsky J, Larsson G (2016) Biocatalysis on the surface of Escherichia coli: melanin pigmentation of the cell exterior. Sci Rep 6:36117. https://doi.org/10. 1038/srep36117

Han H, Iakovenko L, Wilson AC (2015) Loss of homogentisate 1,2dioxygenase activity in Bacillus anthracis results in accumulation of protective pigment. PLoS One 10:e0128967. https://doi.org/10. 1371/journal.pone. 0128967

Harir M, Bellahcene M, Baratto MC, Pollini S, Rossolini GM, Trabalzini L, Fatarella E, Pogni R (2018) Isolation and characterization of a novel tyrosinase produced by Sahara soil actinobacteria and immobilization on nylon nanofiber membranes. J Biotechnol 265:54-64. https://doi.org/10.1016/j.jbiotec.2017.11.004

Hawkins FK, Johnston AW (1988) Transcription of a Rhizobium leguminosarum biovar phaseoli gene needed for melanin synthesis is activated by nifA of Rhizobium and Klebsiella pneumoniae. Mol Microbiol 2:331-337. https://doi.org/10.1111/j.1365-2958.1988. tb00036.x

He P, Moran GR (2009) We two alone will sing: the two-substrate alphaketo acid-dependent oxygenases. Curr Opin Chem Biol 13:443450. https://doi.org/10.1016/j.cbpa.2009.06.012

Held T, Kutzner HJ (1990) Transcription of the tyrosinase gene in Streptomyces michiganensis DSM 40015 is induced by copper and repressed by ammonium. J Gen Microbiol 136:2413-2419

Hernández-Romero D, Solano F, Sanchez-Amat A (2005) Polyphenol oxidase activity expression in Ralstonia solanacearum. Appl Environ Microbiol 71:6808-6815. https://doi.org/10.1128/AEM. 71.11.6808-6815.2005

Herrera MC, Krell T, Zhang X, Ramos JL (2009) PhhR binds to target sequences at different distances with respect to RNA polymerase in 
order to activate transcription. J Mol Biol 394:576-586. https://doi. org/10.1016/j.jmb.2009.09.045

Herter S, Schmidt M, Thompson ML, Mikolasch A, Schauer F (2011) A new phenol oxidase produced during melanogenesis and encystment stage in the nitrogen-fixing soil bacterium Azotobacter chroococcum. Appl Microbiol Biotechnol 90:1037-1049. https:// doi.org/10.1007/s00253-011-3093-x

Hocquet D, Petitjean M, Rohmer L, Valot B, Kulasekara HD, Bedel E, Bertrand X, Plésiat P, Köhler T, Pantel A, Jacobs MA, Hoffman LR, Miller SI (2016) Pyomelanin-producing Pseudomonas aeruginosa selected during chronic infections have a large chromosomal deletion which confers resistance to pyocins. Environ Microbiol 18: 3482-3493. https://doi.org/10.1111/1462-2920.13336

Hullo MF, Moszer I, Danchin A, Martin-Verstraete I (2001) CotA of Bacillus subtilis is a copper-dependent laccase. J Bacteriol 183: 5426-5430. https://doi.org/10.1128/jb.183.18.5426-5430.2001

Hunter RC, Newman DK (2010) A putative ABC transporter, HatABCDE, is among molecular determinants of pyomelanin production in Pseudomonas aeruginosa. J Bacteriol 192:5962-5971. https://doi.org/10.1128/JB.01021-10

Ikeda K, Masujima T, Sugiyama M (1996) Effects of methionine and $\mathrm{Cu}^{2+}$ on the expression of tyrosinase activity in Streptomyces castaneoglobisporus. J Biochem 120:1141-1145. https://doi.org/ 10.1093/oxfordjournals.jbchem.a021533

Katz E, Betancourt A (1988) Induction of tyrosinase by L-methionine in Streptomyces antibioticus. Can J Microbiol 34:1297-1303. https:// doi.org/10.1139/m88-227

Keith KE, Killip L, He P, Moran GR, Valvano MA (2007) Burkholderia cenocepacia $\mathrm{C} 5424$ produces a pigment with antioxidant properties using a homogentisate intermediate. J Bacteriol 189:9057-9065. https://doi.org/10.1128/JB.00436-07

Kelley SK, Coyne VE, Sledjeski DD, Claiborne Fuqua W, Weiner RM (1990) Identification of a tyrosinasse from a periphytic marine bacterium. FEMS Microbiol Lett 67:275-279. https://doi.org/10.1016/ 0378-1097(90)90008-E

Kimura T, Fukuda W, Sanada T, Imanaka T (2015) Characterization of water-soluble dark-brown pigment from Antarctic bacterium, Lysobacter oligotrophicus. J Biosci Bioeng 120:58-61. https://doi. org/10.1016/j.jbiosc.2014.11.020

Kiran GS, Dhasayan A, Lipton AN, Selvin J, Arasu MV, Al-Dhabi NA (2014) Melanin-templated rapid synthesis of silver nanostructures. J Nanobiotechnology 12:18. https://doi.org/10.1186/1477-3155-1218

Kiran GS, Jackson SA, Priyadharsini S, Dobson ADW, Selvin J (2017) Synthesis of Nm-PHB (nanomelanin-polyhydroxy butyrate) nanocomposite film and its protective effect against biofilm-forming multi drug resistant Staphylococcus aureus. Sci Rep 7:9167. https://doi.org/10.1038/s41598-017-08816-y

Kotob SI, Coon SL, Quintero EJ, Weiner RM (1995) Homogentisic acid is the primary precursor of melanin synthesis in Vibrio cholerae, a Hyphomonas strain, and Shewanella colwelliana. Appl Environ Microbiol 61:1620-1622

Kurian NK, Bhat SG (2018) Data on the characterization of noncytotoxic pyomelanin produced by marine Pseudomonas stutzeri BTCZ10 with cosmetological importance. Data Brief 18:18891894. https://doi.org/10.1016/j.dib.2018.04.123

Lagunas-Muñoz VH, Cabrera-Valladares N, Bolívar F, Gosset G, Martínez A (2006) Optimum melanin production using recombinant Escherichia coli. J Appl Microbiol 101:1002-1008. https://doi.org/ 10.1111/j.1365-2672.2006.03013.x

Lerch K, Ettinger L (1972) Purification and characterization of a tyrosinase from Streptomyces glaucescens. Eur J Biochem 31:427-437

Leu WM, Chen LY, Liaw LL, Lee YH (1992) Secretion of the Streptomyces tyrosinase is mediated through its trans-activator protein, MelC1. J Biol Chem 267:20108-20113
Li C, Ji C, Tang B (2018) Purification, characterisation and biological activity of melanin from Streptomyces sp. FEMS Microbiol Lett 365(19). https://doi.org/10.1093/femsle/fny077

Liu N, Zhang T, Wang YJ, Huang YP, Ou JH, Shen P (2004) A heat inducible tyrosinase with distinct properties from Bacillus thuringiensis. Lett Appl Microbiol 39:407-412. https://doi.org/10. 1111/j.1472-765X.2004.01599.x

Liu F, Yang W, Ruan L, Sun M (2013) A Bacillus thuringiensis host strain with high melanin production for preparation of light-stable biopesticides. Ann Microbiol 63:1131-1135. https://doi.org/10.1007/ s13213-012-0570-0

López-Serrano D, Solano F, Sanchez-Amat A (2004) Identification of an operon involved in tyrosinase activity and melanin synthesis in Marinomonas mediterranea. Gene 342:179-187. https://doi.org/ 10.1016/j.gene.2004.08.003

Loprasert S, Whangsuk W, Dubbs JM, Sallabhan R, Somsongkul K, Mongkolsuk S (2007) HpdR is a transcriptional activator of Sinorhizobium meliloti hpdA, which encodes a herbicide-targeted 4-hydroxyphenylpyruvate dioxygenase. J Bacteriol 189:3660 3664. https://doi.org/10.1128/JB.01662-06

Lucas-Elío P, Solano F, Sanchez-Amat A (2002) Regulation of polyphenol oxidase activities and melanin synthesis in Marinomonas mediterranea: identification of $p p o S$, a gene encoding a sensor histidine kinase. Microbiology 148:2457-2466. https://doi.org/10. 1099/00221287-148-8-2457

Madhusudhan DN, Mazhari BB, Dastager SG, Agsar D (2014) Production and cytotoxicity of extracellular insoluble and droplets of soluble melanin by Streptomyces lusitanus DMZ-3. Biomed Res Int 2014:306895. https://doi.org/10.1155/2014/306895

Manirethan V, Raval K, Rajan R, Thaira H, Balakrishnan RM (2018) Data on the removal of heavy metals from aqueous solution by adsorption using melanin nanopigment obtained from marine source: Pseudomonas stutzeri. Data in brief 20:178-189. https:// doi.org/10.1016/j.dib.2018.07.065

Manivasagan P, Venkatesan J, Senthilkumar K, Sivakumar K, Kim SK (2013) Isolation and characterization of biologically active melanin from Actinoalloteichus sp. MA-32. Int J Biol Macromol 58:263274. https://doi.org/10.1016/j.ijbiomac.2013.04.041

Matoba Y, Kumagai T, Yamamoto A, Yoshitsu H, Sugiyama M (2006) Crystallographic evidence that the dinuclear copper center of tyrosinase is flexible during catalysis. J Biol Chem 281:8981-8990. https://doi.org/10.1074/jbc.M509785200

McFall E, Newman EB (1996) Amino acids as carbon sources. In: Neidhardt FC, Curtiss R III, Ingraham JL, Lin EC, Low KB, Magasanik B, Reznikoff WS, Riley M, Schaechter M, Umbarger HE (eds) Escherichia coli and Salmonella: cellular and molecular biology, 2nd edn. ASM Press, Washington, DC, pp 358-379

McMahon AM, Doyle EM, Brooks S, O’Connor KE (2007) Biochemical characterisation of the coexisting tyrosinase and laccase in the soil bacterium Pseudomonas putida F6. Enzym Microb Technol 40: 1435-1441. https://doi.org/10.1016/j.enzmictec.2006.10.020

Mekala LP, Mohammed M, Chinthalapati S, Chinthalapati VR (2019) Pyomelanin production: insights into the incomplete aerobic 1phenylalanine catabolism of a photosynthetic bacterium, Rubrivivax benzoatilyticus JA2. Int J Biol Macromol 126:755764. https://doi.org/10.1016/j.ijbiomac.2018.12.142

Mercado-Blanco J, García F, Fernández-López M, Olivares J (1993) Melanin production by Rhizobium meliloti GR4 is linked to nonsymbiotic plasmid pRmeGR4b: cloning, sequencing, and expression of the tyrosinase gene mepA. J Bacteriol 175:5403-5410. https://doi.org/10.1128/jb.175.17.5403-5410.1993

Mistry JB, Bukhari M, Taylor AM (2013) Alkaptonuria. Rare Dis 1: e27475. https://doi.org/10.4161/rdis.27475

Noorian P, Hu J, Chen Z, Kjelleberg S, Wilkins MR, Sun S, McDougald D (2017) Pyomelanin produced by Vibrio cholerae confers 
resistance to predation by Acanthamoeba castellanii. FEMS Microbiol Ecol 93(12). https://doi.org/10.1093/femsec/fix147

Nosanchuk JD, Casadevall A (2003) The contribution of melanin to microbial pathogenesis. Cell Microbiol 5:203-223. https://doi.org/10. 1046/j.1462-5814.2003.00268.x

Nosanchuk JD, Casadevall A (2006) Impact of melanin on microbial virulence and clinical resistance to antimicrobial compounds. Antimicrob Agents Chemother 50:3519-3528. https://doi.org/10. 1128/AAC.00545-06

Orlandi VT, Bolognese F, Chiodaroli L, Tolker-Nielsen T, Barbieri P (2015) Pigments influence the tolerance of Pseudomonas aeruginosa PAO1 to photodynamically induced oxidative stress. Microbiology 161:2298-2309. https://doi.org/10.1099/mic.0. 000193

Palmer GC, Palmer KL, Jorth PA, Whiteley M (2010) Characterization of the Pseudomonas aeruginosa transcriptional response to phenylalanine and tyrosine. J Bacteriol 192:2722-2728. https://doi.org/10. 1128/JB.00112-10

Pavan ME, Abbott SL, Zorzópulos J, Janda JM (2000) Aeromonas salmonicida subsp. pectinolytica subsp. nov., a new pectinasepositive subspecies isolated from a heavily polluted river. Int $\mathrm{J}$ Syst Evol Microbiol 50(Pt 3):1119-1124. https://doi.org/10.1099/ 00207713-50-3-1119

Pavan ME, Pavan EE, López NI, Levin L, Pettinari MJ (2015) Living in an extremely polluted environment: clues from the genome of melanin-producing Aeromonas salmonicida subsp. pectinolytica 34mel ${ }^{\mathrm{T}}$. Appl Environ Microbiol 81:5235-5248. https://doi.org/10. 1128/AEM.00903-15

Pavan ME, Solar Venero E, Egoburo DE, Pavan EE, López NI, Julia Pettinari M (2019) Glycerol inhibition of melanin biosynthesis in the environmental Aeromonas salmonicida $34 \mathrm{mel}^{\mathrm{T}}$. Appl Microbiol Biotechnol 103:1865-1876. https://doi.org/10.1007/s00253-0189545-9

Piñero S, Rivera J, Romero D, Cevallos MA, Martínez A, Bolívar F, Gosset G (2007) Tyrosinase from Rhizobium etli is involved in nodulation efficiency and symbiosis-associated stress resistance. J Mol Microbiol Biotechnol 13:35-44. https://doi.org/10.1159/000103595

Plonka PM, Grabacka M (2006) Melanin synthesis in microorganisms biotechnological and medical aspects. Acta Biochim Pol 53:429443

Pomerantz SH, Murthy VV (1974) Purification and properties of tyrosinases from Vibrio tyrosinaticus. Arch Biochem Biophys 160:73-82

Reiss R, Ihssen J, Thöny-Meyer L (2011) Bacillus pumilus laccase: a heat stable enzyme with a wide substrate spectrum. BMC Biotechnol 11: 9. https://doi.org/10.1186/1472-6750-11-9

Rizvi A, Ahmed B, Zaidi A, Khan MS (2019) Bioreduction of toxicity influenced by bioactive molecules secreted under metal stress by Azotobacter chroococcum. Ecotoxicology 28:302-322. https://doi. org/10.1007/s10646-019-02023-3

Rodríguez-Rojas A, Mena A, Martín S, Borrell N, Oliver A, Blázquez J (2009) Inactivation of the $h m g A$ gene of Pseudomonas aeruginosa leads to pyomelanin hyperproduction, stress resistance and increased persistence in chronic lung infection. Microbiology 155: 1050-1057. https://doi.org/10.1099/mic.0.024745-0

Ruan L, Yu Z, Fang B, He W, Wang Y, Shen P (2004) Melanin pigment formation and increased UV resistance in Bacillus thuringiensis following high temperature induction. System Appl Microbiol 27:286289. https://doi.org/10.1078/0723-2020-00265

Sajjan S, Kulkarni G, Yaligara V, Kyoung L, Karegoudar TB (2010) Purification and physiochemical characterization of melanin pigment from Klebsiella sp. GSK J Microbiol Biotechnol 20:15131520. https://doi.org/10.4014/jmb.1002.02006

Sanchez-Amat A, Solano F (1997) A pluripotent polyphenol oxidase from the melanogenic marine Alteromonas sp shares catalytic capabilities of tyrosinases and laccases. Biochem Biophys Res Commun 240:787-792
Sanchez-Amat A, Ruzafa C, Solano F (1998) Comparative tyrosine degradation in Vibrio cholerae strains. The strain ATCC 14035 as a prokaryotic melanogenic model of homogentisate-releasing cell. Comp Biochem Physiol B Biochem Mol Biol 119:557-562. https://doi.org/10.1016/S0305-0491(98)00028-5

Sanchez-Amat A, Solano F, Lucas-Elío P (2010) Finding new enzymes from bacterial physiology: a successful approach illustrated by the detection of novel oxidases in Marinomonas mediterranea. Mar Drugs 8:519-541. https://doi.org/10.3390/md8030519

Schaerlaekens K, Schierová M, Lammertyn E, Geukens N, Anné J, Van Mellaert L (2001) Twin-arginine translocation pathway in Streptomyces lividans. J Bacteriol 183:6727-6732. https://doi.org/ 10.1128/JB.183.23.6727-6732.2001

Shivprasad S, Page WJ (1989) Catechol formation and melanization by $\mathrm{Na}^{+}$-dependent Azotobacter chroococcum: a protective mechanism for aeroadaptation? Appl Environ Microbiol 55:1811-1817

Shuster V, Fishman A (2009) Isolation, cloning and characterization of a tyrosinase with improved activity in organic solvents from Bacillus megaterium. J Mol Microbiol Biotechnol 17:188-200. https://doi. org $/ 10.1159 / 000233506$

Silva C, Santos A, Salazar R, Lamilla C, Pavez B, Meza P, Hunter R, Barrientos L (2019) Evaluation of dye sensitized solar cells based on a pigment obtained from Antarctic Streptomyces fildesensis. Sol Energy 181:379-385. https://doi.org/10.1016/j.solener.2019.01.035

Singh G, Bhalla A, Kaur P, Capalash N, Sharma P (2011) Laccase from prokaryotes: a new source for an old enzyme. Rev Environ Sci Biotechnol 10:309-326. https://doi.org/10.1007/s11157-011-92574

Singh S, Malhotra AG, Pandey A, Pandey KM (2013) Computational model for pathway reconstruction to unravel the evolutionary significance of melanin synthesis. Bioinformation 9:94-100. https:// doi.org/10.6026/97320630009094

Singh D, Kumar J, Kumar A (2018) Isolation of pyomelanin from bacteria and evidences showing its synthesis by 4 hydroxyphenylpyruvate dioxygenase enzyme encoded by $h p p D$ gene. Int J Biol Macromol 119:864-873. https://doi.org/10.1016/j. ijbiomac.2018.08.003

Skinner CE (1938) The "tyrosinase reaction" of the actinomycetes. J Bacteriol 35:415-424

Solano F (2014) Melanins: skin pigments and much more - types, structural models, biological functions, and formation routes. New Journal of Science 2014:Article ID 498276. https://doi.org/10. $1155 / 2014 / 498276$

Solano F, Lucas-Elío P, Fernández E, Sanchez-Amat A (2000) Marinomonas mediterranea MMB-1 transposon mutagenesis: isolation of a multipotent polyphenol oxidase mutant. J Bacteriol 182: 3754-3760. https://doi.org/10.1128/jb.182.13.3754-3760.2000

Stepanova V, Rodionov DA (2011) Genomic analysis of transcriptional regulation of aromatic amino acid metabolism in gammaproteobacteria. Department of Bioengineering and Bioinformatics of MV Lomonosov Moscow State University 352: 186-188

Surwase SN, Jadhav SB, Phugare SS, Jadhav JP (2013) Optimization of melanin production by Brevundimonas sp. SGJ using response surface methodology. 3. Biotech 3:187-194. https://doi.org/10.1007/ s13205-012-0082-4

Takano H, Asano K, Beppu T, Ueda K (2007) Role of $\sigma^{\mathrm{H}}$ paralogs in intracellular melanin formation and spore development in Streptomyces griseus. Gene 393:43-52. https://doi.org/10.1016/j. gene.2007.01.026

Tarangini K, Mishra S (2013) Production, characterization and analysis of melanin from isolated marine Pseudomonas sp. using vegetable waste. Res J Engineering Sci 2:40-46

Tarangini K, Mishra S (2014) Production of melanin by soil microbial isolate on fruit waste extract: two step optimization of key 
parameters. Biotechnol Rep 4:139-146. https://doi.org/10.1016/j. btre.2014.10.001

Thaira H, Raval K, Manirethan V, Balakrishnan RM (2019) Melanin nano-pigments for heavy metal remediation from water. Sep Sci Technol 54:265-274. https://doi.org/10.1080/01496395.2018. 1443132

Toledo AV, Franco MEE, López SMY, Troncozo MI, Saparrat MCN, Balatti PA (2017) Melanins in fungi: types, localization and putative biological roles. Physiol Mol Plant Path 99:2-6. https://doi.org/10. 1016/j.pmpp.2017.04.004

Trias J, Viñas M, Guinea J, Lorèn JG (1989) Brown pigmentation in Serratia marcescens cultures associated with tyrosine metabolism. Can J Microbiol 35:1037-1042

Tsai TY, Lee YH (1998) Roles of copper ligands in the activation and secretion of Streptomyces tyrosinase. J Biol Chem 273:1924319250. https://doi.org/10.1074/jbc.273.30.19243

Tsai YJ, Ouyang CY, Ma SY, Tsai DY, Tseng HW, Yeh YC (2014) Biosynthesis and display of diverse metal nanoparticles by recombinant Escherichia coli. RSC Adv 4:58717-58719. https://doi.org/ $10.1039 / \mathrm{c} 4 \mathrm{ra} 12805 \mathrm{~b}$

Turick CE, Tisa LS, Caccavo F Jr (2002) Melanin production and use as a soluble electron shuttle for Fe(III) oxide reduction and as a terminal electron acceptor by Shewanella algae BrY. Appl Environ Microbiol 68:2436-2444. https://doi.org/10.1128/AEM.68.5.24362444.2002

Turick CE, Knox AS, Leverette CL, Kritzas YG (2008) In situ uranium stabilization by microbial metabolites. J Environ Radioact 99:890 899. https://doi.org/10.1016/j.jenvrad.2007.11.020

Turick CE, Beliaev AS, Zakrajsek BA, Reardon CL, Lowy DA, Poppy TE, Maloney A, Ekechukwu AA (2009) The role of 4hydroxyphenylpyruvate dioxygenase in enhancement of solidphase electron transfer by Shewanella oneidensis MR-1. FEMS Microbiol Ecol 68:223-235. https://doi.org/10.1111/j.1574-6941. 2009.00670.x

Turick CE, Knox AS, Becnel JM, Ekechukwu AA, Milliken CE (2010) Properties and function of pyomelanin. In: Elnashar M (ed) Biopolymers, 1st edn. Sciyo, Rijeka, pp 449-472. https://doi.org/ $10.5772 / 10273$

Unuofin JO, Okoh AI, Nwodo UU (2019) Aptitude of oxidative enzymes for treatment of wastewater pollutants: a laccase perspective. Molecules 24:2064. https://doi.org/10.3390/molecules24112064

Valeru SP, Rompikuntal PK, Ishikawa T, Vaitkevicius K, Sjöling A, Dolganov N, Zhu J, Schoolnik G, Wai SN (2009) Role of melanin pigment in expression of Vibrio cholerae virulence factors. Infect Immun 77:935-942. https://doi.org/10.1128/LAI.00929-08

Vijayan V, Jasmin C, Anas A, Kuttan SP, Vinothkumar S, Subrayan PP, Nair S (2017) Sponge-associated bacteria produce non-cytotoxic melanin which protects animal cells from photo-toxicity. Appl Biochem Biotechnol 183:396-411. https://doi.org/10.1007/ s12010-017-2453-0

Wang R, Wang H, Zhou H, Wang Y, Yue J, Diao B, Kan B (2011) Characters of homogentisate oxygenase gene mutation and high clonality of the natural pigment-producing Vibrio cholerae strains. BMC Microbiol 11:109. https://doi.org/10.1186/1471-2180-11-109

Wang H, Qiao Y, Chai B, Qiu C, Chen X (2015) Identification and molecular characterization of the homogentisate pathway responsible for pyomelanin production, the major melanin constituents in Aeromonas media WS. PLoS One 10:e0120923. https://doi.org/10. 1371/journal.pone.0120923

Wang L, Li Y, Li Y (2019) Metal ions driven production, characterization and bioactivity of extracellular melanin from Streptomyces sp. ZL24. Int J Biol Macromol 123:521-530. https://doi.org/10.1016/j. ijbiomac.2018.11.061

Yabuuchi E, Ohyama A (1972) Characterization of "pyomelanin"-producing strains of Pseudomonas aeruginosa. Int J Syst Bacteriol 22: 53-64. https://doi.org/10.1099/00207713-22-2-53

Zaidi KU, Ali AS, Ali SA, Naaz I $(2014,2014)$ Microbial tyrosinases: promising enzymes for pharmaceutical, food bioprocessing, and environmental industry. Biochem Res Int. https://doi.org/10.1155/ 2014/854687

Zeng Z, Cai X, Wang P, Guo Y, Liu X, Li B, Wang X (2017a) Biofilm formation and heat stress induce pyomelanin production in deep-sea Pseudoalteromonas sp. SM9913. Front Microbiol 8:1822. https:// doi.org/10.3389/fmicb.2017.01822

Zeng Z, Guo XP, Cai X, Wang P, Li B, Yang JL, Wang X (2017b) Pyomelanin from Pseudoalteromonas lipolytica reduces biofouling. Microb Biotechnol 10:1718-1731. https://doi.org/10.1111/17517915.12773

Zerrad A, Anissi J, Ghanam J, Sendide K, El Hassouni M (2014) Antioxidant and antimicrobial activities of melanin produced by a Pseudomonas balearica strain. J Biotechnol Lett 5:87-94

Zheng H, Chatfield CH, Liles MR, Cianciotto NP (2013) Secreted pyomelanin of Legionella pneumophila promotes bacterial iron uptake and growth under iron-limiting conditions. Infect Immun 81: 4182-4191. https://doi.org/10.1128/IAI.00858-13

Zhu D, He X, Zhou X, Deng Z (2005) Expression of the melC operon in several Streptomyces strains is positively regulated by AdpA, an AraC family transcriptional regulator involved in morphological development in Streptomyces coelicolor. J Bacteriol 187:3180 3187. https://doi.org/10.1128/JB.187.9.3180-3187.2005

Publisher's note Springer Nature remains neutral with regard to jurisdictional claims in published maps and institutional affiliations. 